\title{
Essay
}

\section{Action, Passion, Crises}

\section{Denis Goldberg}

South African anti apartheid activist, Cape Town, South Africa; dengoldberg@mweb.co.za

Academic Editor: Annabel Martín

Received: 17 February 2017; Accepted: 12 April 2017; Published: 18 April 2017

The title of this speech is taken from a remark of the renowned Judge Oliver Wendell Holmes Jr: "When we were young our hearts were touched with fire...[and as]...life is action and passion, it is required of [one] that [one] should share the passion and action of [one's] time, at the peril of being judged not to have lived."

I think that I can fairly say that I have lived a life of passion and action and faced several crises, some private, some public, and some both public and private.

I have loved and been loved and buried two wives who died after long illnesses. I have buried my daughter who died at age 46 from cancer. All of this is in the private sphere of my life, which included being unable to attend the funerals of my Mother and then my Father because I was in prison for 22 years. I also created crises in the lives of my wife and two children because I consciously placed myself in harm's way because I believe that what is important in being human is to act with passion, with determination, and to overcome what is morally unacceptable in our society. Spouses and children bear the brunt of such a life. One might say they "paid the price" for the freedom we have won.

Facing the gallows in the famous Rivonia Trial was more than trying, and all the possible word play on 'trying' adds to the depth of the passion and thus of that crisis in my life. Having to deal with the thought of execution at age 31 for demanding justice for all the people of my country was both public and private. Public because the actions of my comrades and I were in the public sphere; the passionate belief in equal rights for all and the right to take action by taking up arms to overthrow a tyrannical unjust regime.

"The tree of liberty must be refreshed from time to time with the blood of patriots and tyrants. It is its natural manure." So said Thomas Jefferson, in defense of those early Americans who opposed the British domination of the American colonies through a wealthy merchant class. He was warning us not to automatically accept the allegedly moral dictates of those in power who assert the right to autocratically decide how we should live our lives. Perhaps those modern-day Americans, who often support tyrants in what they perceive to be American interests, should see that they have not understood Jefferson's warning, thereby involving all of us in one crisis after another!

\section{Gender}

I am hosted by the Gender Research Institute at Dartmouth and must tell you that in prison there was time, endless time, to read and reflect. Issues of feminism and gender equality became a topic of interest and I think I now have greater understanding of these issues than I did previously. Translating it into interpersonal practice is less certain than knowing when one has got it wrong!

Towards end of 19th century, a growing literature on women's rights appeared. In South Africa, Olive Schreiner's great novel, Story of an African Farm, for example. Her work, Woman and Labour is said to be the best expression of her concerns with socialism and gender equality. She had a vision of a non-racist, non-sexist South Africa. She opposed the British imperialists during the Boer War and the First World War. During the last years of her life (she died in 1920) she was increasingly isolated from white society. However, she continued to be involved in politics and was determined to make her mark on a new constitution, especially through her work Closer Union, in which she argued for 
more rights not only for blacks but also for women. She also joined the newly founded Cape Branch of the Women's Enfranchisement League in 1907. She became its vice-president, but withdrew her support when some of the other branches wished to exclude black women from the vote. [This is from Wikipedia for easy reference.]

I also read about the Communist Rosa Luxemburg in Germany and many Bolshevik women in Russia who claimed their "equality." There were also many women in the Socialist Party of Germany (Social Democrats) who actively promoted women's rights. Simone de Beauvoir's the Second Sex provides an existential approach to the "status of women," and Juliet Mitchell in Britain in the 1970s began to provide a Marxist approach to the oppression of women, raising issues of social class and bias against women. These issues came to the fore during WWI, when women worked in munitions factories while men were fighting and were then sent home again after the war. The same happened during WWII, but now there was a boom during the Korean war and industrialists found that they could employ women at lower rates of pay than men in the factories, and as we know low wages make fat profits. Interestingly, male workers sided with employers against women workers. But now the die was cast and probably for the first time working class women in the industrialized countries began demanding equal pay for equal work and their rights. Today in the advanced countries we have paid maternity leave, for example, and other enforceable rights.

We said in apartheid times that the oppression of the majority of women in South Africa was threefold: as women, as workers and as black workers. During the struggles against apartheid, O.R. Tambo, the leader of the African National Congress during 30 years of exile to the dawn of freedom, would say that the freedom of women is a task for women and men together. These issues have been formally resolved in South Africa's post-apartheid Constitution of 1996, which guarantees equal rights to all adults.

Today the ANC, as the ruling party in the national government and in eight of the nine provinces, ensures equal representation of women and men in elected assemblies by having men and women candidates listed alternatively. Since the election is based on proportional representation by list votes, this automatically achieves the goal of equal representation. The ANC seeks to achieve the same result in municipal elections by different means because there the candidates are elected in each ward, in addition, a smaller number are elected by proportional representation of votes cast. Many executive mayors are women in ANC-led municipalities. And in the provinces, more than half the premiers are women as a matter of policy of the ruling party.

There is conflict, however, with traditional leaders, read "chiefs," who demand their allegedly traditional rights under African custom. These customs have often been distorted under colonial and apartheid rule. Chiefs were made part of the state administration and could be installed and dismissed by the white settler, colonial, apartheid government, depending on which stage of our history we are considering. The traditional, fundamentally democratic processes were undermined by an autocratic rule directed by "Native Commissioners" and other officials. There is currently a bill before Parliament intended to regulate the powers of the traditional leaders. Some of its provisions are in direct conflict with the Constitution. Essentially, women are always minors in customary law and unable to represent themselves or speak at tribal courts and other meetings. The bill has been stalled for years because of this conflict.

In practice, extreme poverty hits women harder because they are left to bring up children on their own, with men frequently making babies and then leaving for newer pastures. (This happens in all societies, which is why there are laws about child support by absent parents-mainly fathers. Laws are one thing, enforcement is another!)

Today, rape, sexual abuse and violence is a serious problem in South Africa that is said to be an act stemming from "powerlessness" rather than erotic sexual behavior. One might also suggest disruption of families and networks in a period of transition. There is no easy explanation. For example, following the collapse of Yugoslavia, when people had intermarried for over two generations, in a period of nationalistic excess rape was a weapon. Why do men see their organs as weapons? 
After our liberation in 1994, I set up Community Health Education And Reconstruction Training [H.E.A.R.T.] as a registered charity in Britain. One of our first successful funding efforts was for Rape Crisis Cape Town. To date, we have sourced mainly from UK and Germany at least 1.6 million dollars. Then, they had one halftime worker. Now they have three offices and a large staff with many volunteers. There are numerous such organisations in other parts of our country.

According to the most recent Human Sciences Research Council report on HIV and AIDS, more women are infected than men. The rates of infection appear to be falling, but the number of people living with HIV/AIDS is increasing because of the extensive treatment programme. Two million people receive ARV [anti retro viral] treatment. Thus, more people survive and live with the disease. There is also a tendency for a new generation of young people to practice unsafe sex, not using condoms and having multiple partners. The Department of Health is seeking ways to deal with the ever changing situation.

The Ministry of Women and Children works to advance the rights in practice of women. The payment of a children's allowance by the government to those in need; for children up to 18 years of age and senior citizens this literally means the difference between starvation and survival. In addition, women with some income can pay child minders while they go out to find paid employment, often extremely menial. We have a long way to go in overcoming the disadvantages that women suffer. It is both a question of material conditions and of mindset.

Women of all classes, education and race have been disadvantaged. Our Employment Equity Act requires that women be represented equally in all places of work above a minimum size. For this purpose, white women who historically come from the most advantaged groups are also included in the provisions of this Act because they were, and still are disadvantaged.

For example, under apartheid there was only one woman judge in our legal system. She was white, an Afrikaans speaker, thus of the ruling group. She has said that she was more or less ignored by male judges, and only after the end of apartheid have more women of all races been appointed to the bench. Presently, about $30 \%$ of judges are women. There are also judicial officers, or magistrates, many of whom are women.

The Department of Justice and Constitutional Development (http:/ / www.justice.gov.za/docs/ articles / 20130510-dm-tranformation.html) states: Today, as "Mandela's children" prepare to vote for the first time, 100 black men and 49 black women, 71 white men and 21 white women serve our nation as judges. They do so knowing that they are part of a judiciary that is coming closer to reflecting the racial and gender composition of South Africa, as is required by our Constitution.

Similar progress has been made in addressing race and gender imbalances in Magistrates Courts. Of the 1661 magistrates, 974 are black and 687 are white; 647 are women and 1014 are men.

Thus progress has been made, but more has to be done and men in such positions have to learn to accept women as equals on the bench and in the legal profession as a whole.

Let me turn to the broader issues of a journey of apartheid racism by law through the years of struggle and imprisonment, freedom, and 20 years into a democratic system that commenced in 1994. I mentioned HIV and AIDS- that's a real crisis for us, with the infection rates that we have. But the biggest anti-retroviral program of any country is being rolled out in our country, and will continue to be rolled out. The research that is being done is also of tremendous importance. It used to take weeks for a test to be undertaken-it now takes $20 \mathrm{~min}$. With a little test strip like for diabetes, if the person is positive it would take a second to know.

Tuberculosis and strains of tuberculosis that are associated with HIV and AIDS have also become a critical issue in the health system that served whites with absolutely the best of all possible care under apartheid. For example, for whites on average, there was one medical doctor, a general practitioner, for 400 people. In addition, they had access to top-notch hospitals, government hospitals, free at point of service, and specialists who are best in the world. For Africans, according to the World Health Organization, there was in various parts of the country, one doctor for 80,000 people or one 
for 120,000 people. In the black township next to Johannesburg, there was one doctor for 3000 people. Imagine getting ill and trying to see a doctor-you just don't get an appointment. Not easily, anyway.

But there was another matter: the gold mines in particular, but mining in general, in South Africa was exempted by a special law from having liability for occupational health diseases. So, miner's, phthisis, which could kill workers, could not be compensated for. Miners would be sent home to the countryside where they came from and were not allowed to bring their families with them to work on the mines. Why? The mines, in a formal statement, in a judicial inquiry into mine wages in 1946, said, "Well you see, the family needs so much money to survive and bring up children who will be the next generation of workers. We provide a barracks for workers, a concrete bed and a place to keep their tin box of possessions. We provide them three meals a day, and that costs us so much per worker. And we then need to pay them enough to send home to their wives to keep them alive. But you see, the women grow a few bags of mealy corn, so we can deduct that from the amount of money needed." A serious calculation. Technically, this was called the cost of labour theory; the cost of reproducing the next generation of workers. And there was a great big capitalist group, the Chamber of Mines, following a Marxist analysis of what it costs to train workers and keep them alive. Such a contradiction in my country-and the judges concerned accepted all these arguments.

And so it continued, that white workers were paid roughly 18 times as much the black workers on the mines. That is how apartheid was maintained, and white workers were made part of the control system and therefore had an interest in maintaining apartheid against all other workers. But miner's phthisis, TB and so on, meant that workers went home to die. There was no compensation. Last year, a new constitutional court ruling struck this down as being unconstitutional against the guarantees of the constitution of equal rights for all. And so the mining companies are facing huge compensation claims. I'm not optimistic about how much the workers are going to get, specifically those who suffered these diseases. Some years ago, a group of miners who suffered from asbestosis sued a mining company, which is based in London now, for their diseases that killed so many people and left so many disabled. And the court ruled in favor of the workers. And the mining company had to pay out millions and then declared themselves bankrupt and said, "Do what you will, we're not paying you." I believe the same thing is going to happen with the gold mines. Many of them have moved out of the country, taken their cash reserves and invested in the London stock exchange and elsewhere, etc. They will always find a way of not paying compensation.

It has taken 20 years of our freedom to undo 100 years of gross oppression and denial of human rights and dignity for the sake of profit. And that is what apartheid was about-a system of cheap labour. Cheap labour that makes fat profits. I am not going to quote all the documentation you can find; when the Union of South Africa was formed by an act of the British parliament in 1910, they were enacting the wishes of the white politicians as to how they would treat people who were not white to ensure sufficient labour for the mines and the farmers, commerce and industry, etc. And the answer was to have no political rights at all, no votes, and no trade union rights. To be in a trade union or bargain collectively was illegal.

Then eventually in 1913, the white parliament passed a law called the Native's Land Act, which left them with $7 \%$ of the land, the most inhospitable land for two thirds of the population, eventually increased to $13 \%$, which meant that black people had to go to work to earn money to survive, because they didn't have land anymore. What happened over hundreds of years in Europe and England was done at the stroke of a pen. Why? Because black farmers were providing the crops to feed the mine workers themselves without any assistance from government and were making it very difficult for white farmers to survive. So government's solution was to get rid of the competition, to create an industrial working class while giving them no rights to land.

To reinforce it, black workers had to, for the first time, begin to pay taxes in cash, which means that you have to go to work. What were those taxes? A hut tax? A wife tax? A dog tax? A cow tax? Taxes which no white paid. If you want money and people are forced to go to work, they also cannot just go to work because they might flood into the town. So, laws were passed that required every black 
male person over the age of 16 to carry a purse, and to not have it on him meant a criminal offense, for which they would go to prison. He was allowed to go to the town to seek a job if he had written permission to go, and if he could not find a job, he had to go home again. People of course stayed, because they needed to feed their families and so 150,000 and sometimes 300,000 people a year went to prison because they wanted to feed their families. And white South Africans said, you see these blacks they have no sense of family. They leave them to go to work in the town. But the law said, even if they found a job on a mine or on a farm, they may not take their families with them. Only the worker can go. I think you might agree it was a pretty immoral system. That was apartheid.

The African national congress was founded in 1912 to combat this upcoming Lands Act and resistance really was quite strong and the attitude was that Africans throughout Southern Africa, and really throughout the British colonies all the way to Tanzania, could be members. It was a sense of Africans regaining the land and their rights. It took a hundred years of conquest of the British from 1805 to 1906 to conquer the people and create this Union of South Africa in 1910. People resisted always, but the resistance took the form of petitioning by educated Africans, translators, civil servants, and minor civil servants. They would say, "when we are civilized, the white man will give us our rights." But those who have oppressed you never find you civilized.

And so in the 1940s, during WWII, when President Roosevelt met with Prime Minister Churchill on a cruiser just off the Atlantic coast of the U.S to declare the Atlantic Charter, the war aims in WWII against Nazi Germany, their aim was the end of colonialism and the equality of all people-and our young educated African people took it seriously. They said, "All people? Then we want to be equal as well," and they formed an African National Congress Youth League, which campaigned against the senior body to turn it into an activist organization with a mass movement: "We are not going to stay unequal forever."

Among the people involved, I mentioned Oliver Tambo earlier, but also Nelson Mandela, as a whole generation of people who took seriously the idea of the ending of colonial oppression and racial oppression. And there were passive resistance campaigns called "the defiance of unjust laws campaign." People would deliberately not have their passes on them; they would enter into black townships where they didn't have permission to go. Others would go into a post office where there were two doors: one for whites, one for blacks. There would be a huge queue of blacks doing the business work of whites, and one or two whites at a separate counter with virtually no one to be served. So, they go in at the "wrong" door, to the "wrong" counter with the idea was that they would bring the justice system to a standstill and compel the government to change.

It was also an organizing mechanism for the African National Congress. When eight thousand people had gone to jail voluntarily for deliberately breaking the law, the government introduced a new law. To break a law, you would get the normal punishment. To break a law for the purpose of protesting against the law was a second crime. For the first crime you might get three months. For the second crime you could get ten years. And when that did not break this protest, they introduced lashing with a cane.

I have been in prison and I have heard it. I have also seen the frame on which people would be strapped, arms out, lying forward, bent over. And we would hear the screams, we would hear the lashing. We would hear the screams and the cane would be soaked in water to make it flexible. Its end was bound with twine in case it might split and damage state property. And having struck with as much force as possible, the guard would then draw the cane across the back to actually cut the skin. The scars remain forever. The wounds heal; what does not heal is the scar in the mind. It did break that protest. I heard people asking earlier about compromise. That is not compromise. That is survival.

I listened to previous young speakers, and I was fascinated by the difference of attitude between that of my comrades and their attitudes; their attitudes were about themselves and their need to take part for themselves and their personal satisfaction. And in the end, compromising, yes you got to eat. Yes, you got to survive, but you continue because the system has not changed. It is a question of how much you can do at a given stage in your life. I worked with comrades and I was married 
and I had children. My wife was an activist. When she was pregnant and the children were young, she could not be out and about and risk being beaten and losing the child. At other times, she was equally as active as I was. I am fascinated (though I do not want to be ageist) to hear a person who is nowhere near 25 years old telling me what life is about, when I have been with people in prison for over 20 years, being with comrades who were nearby on death row in a hanging prison. And hangings took place every week of prisoners in general; murder carried a death sentence just as rape did if a black person raped a white person. 150-200 people a year were hanged, and we would hear them. Hear the trapdoors being tested, the clanking of the chains as people were brought in to be hanged. We would hear prisoners begin to sing as the sheriff came along to tell them their time had come the next morning. They would start singing hymns and break off and start again and break off until there were 3000 people singing together right through the night. And then the trapdoors would fall and the singing would stop as though an electric switch had been thrown.

I was in that prison with some of my comrades for just less than three years. On the days there were going to be hangings, we could not go into our exercise yard, we lived almost under the gallows. It was a dreadful experience, worse for the prisoners, of course. But what brutality. And there were prison guards in that prison who were required to take a turn at the hangings, but there were some guards who chose to be there every week. They enjoyed the hangings. It is unbelievable what people can do. People lose wives, their children. That is what we lived through and yet you see that did not break us, did not break my comrades.

At the same time, we had some of our comrades who were sentenced to death, political comrades, and they would sing on death row freedom songs for 20 min just before lights out at 8 o'clock at night, the most beautiful harmonies. They would sing about their struggle, and why they took part. They knew what they were there for and what they were fighting for and they taught 3000 people to sing freedom songs with them until the whole place was jumping with these ideas. And I can tell you I am not a musician. I am not very musical, but I did teach myself to play the recorder and to eventually play the freedom songs as well, and that was how we communicated. After years, these guys' sentences were commuted. Years later, I met one of them who rushed over-he had heard that I was at a place where he was as well-to say that my playing to them gave them such hope and courage that they were not alone. Music is wonderful. It is such a communicator.

Shortly after I was sentenced to life imprisonment, there were four of us together, whites, who were kept separately: racism in prison as well. And three other comrades were going to the gallows and were singing freedom songs as they went defiantly and my three comrades had been there before me, asking not to sing with them because of the fear of punishment. We escaped the death sentence-I do not know how, but we did. I listened to them-I did not have the courage then to sing. And I can tell you that courage is a fluctuating thing. There are times when you can put your head up above the battlements and times when you keep your head down and regain your strength and go on with your struggle. And to say, I cannot go on with the struggle because it makes me unhappy-that is out of my vocabulary, I am afraid. It seems to me to be self-indulgent.

I want to cite the writing of Viktor Frankl, psychiatrist, in his work entitled Man's Search for Meaning. A follower of Freud who survived the Nazi concentration camps, he wrote about his experience and he summarized it more or less like this: that Freud thought that the sex drive was the main force in life. His disciple Adler thought it was the quest for power, and Frankl came to the conclusion that the driving force was the search for meaning, the meaning of life. Those who felt their lives had no meaning gave up, they gave up life and died very quickly. The conditions were like hell-bad food, diseases. But those who have a sense that they are going to survive, they are going to look after others, they are going to make a better world-they lasted longer, as did he. He then wrote this book and subsequent others. I didn't know about his book until around 2006, when I was given a copy. Forty years after, I thought life is wonderful. I read this book and what a nice feeling that this great philosophical intellectual had the same experience that I had. I felt it was good, I felt right. 
And he is right. And those who say life is about personal happiness and to hell with anybody else, I think they got it wrong. I really do.

I tried to say earlier in our little session over lunch, the very same students come to this university to study in the grove of academe. And how did they get here-they went through a public school system. Through taxes, through people who were trained at other colleges, taught knowledge that has been built up over millennia. That is why we footnote our scientific papers. To show that we are following a tradition. It has now become a question of priority and who is going to get paid for having this new insight. But it was Sir Isaac Newton, the inventor of the concept of gravity in the English-speaking world, who said, "We stand on the shoulders of giants so that we may see further," and more recently, at a meeting of the American Association for the Advancement of Sciences, the president said, "We stand on the shoulders of giants and they're sitting next to us here in the hall."

Knowledge is a social phenomenon, it is not individual. Languages are social phenomena; we express knowledge through our socially developed language. If we did not have a common understanding of what is blue and black, what is up and down, what is sky and what is water, wind, fire, earth, we would not be able to communicate with each other. So these students come here to a social institution and somehow get socialized into being individualists and forget that we are part of a whole. Interestingly, there is a nice contradiction in their behavior, because they feel they have to be involved in changing society but when it gets difficult, they drop out and say, "I got to be happy." But I could not be happy if I dropped out, because my comrades were still in prison when I had been released. And the people of my country are still poor; we haven't overcome a legacy of over 400 years of institutionalized racism. I felt that I have to gently say that I disagree with my younger fellow strugglers for human justice. They seem to me to be self-indulgent.

Thank you for your attention.

Conflicts of Interest: The author declares no conflict of interest.

(C) 2017 by the author. Licensee MDPI, Basel, Switzerland. This article is an open access article distributed under the terms and conditions of the Creative Commons Attribution (CC BY) license (http:/ / creativecommons.org/licenses/by/4.0/). 